\title{
EVALUASI PRODUKSI DAN KECERNAAN BAHAN KERING RUMPUT LAPANG DAN RUMPUT GAJAH
}

\author{
R. Z. Islami ${ }^{1}$, N. P. Indriani ${ }^{1}$, I. Susilawati ${ }^{1}$, H. K. Mustafa ${ }^{1}$, S. Nurjannah ${ }^{2}$, dan U. H. Tanuwiria ${ }^{1}$ \\ ${ }^{1}$ Fakultas Peternakan, Universitas Padjadjaran \\ ${ }^{2}$ Program Studi Peternakan, Fakultas Pertanian, Universitas Insan Cendekia Mandiri \\ e-mail: romi.zamhir@unpad.ac.id
}

\begin{abstract}
ABSTRAK
Rumput lapang dan rumput gajah merupakan hijauan makanan ternak yg sering diberikan pada ternak ruminansia. Penelitian bertujuan untuk mengevaluasi produksi dan kecernaan bahan kering dari rumput lapang dan rumput gajah. Penelitian dilakukan secara eksperimental menggunakan RAL. Peubah yang diamati meliputi berat segar, berat kering, dan kecernaan bahan kering rumput yang berasal dari 10 ulangan kuadrat rumput lapang dan 10 ulangan rumput gajah. Data yang diperoleh dianalisis statistik dengan uji $\mathrm{t}$ yang digunakan untuk mengetahui perbedaan rataan produksi dan kecernaan. Hasil penelitian menunjukkan produksi BS rumput lapang lebih baik dari rumput gajah (256,35 g vs 220,93 g), sedangkan produksi BK $(37,58$ g vs 46,62 g) dan kecernaan BK (47,46\% vs 57,01\%) rumput lapang lebih rendah dibanding rumput gajah.
\end{abstract}

Kata kunci: rumput, produksi, kecernaan bahan kering

\section{EVALUATION OF PRODUCTION AND DRY MATTER DIGESTIBILITY OF NATIVE GRASS AND ELEPHANT GRASS}

\begin{abstract}
Field grass and elephant grass is a feed forage to used for ruminants. The aim of this research was to evaluate of the production and dry matter digestibility of field grass and elephant grass. Both are included in the fodder forage. The method used was experimental by using completely randomized design (CRD). This research data was taken from 10 field grass and 10 elephant grass. The observed variable were observed included fresh matter, dry matter, and dry matter digestibility of grass. This research was using t-test to know the difference of production and digestibility. The results showed that fresh weight productivity of field grass was better than elephant grass $(256,35 \mathrm{~g}$ vs $220,93 \mathrm{~g}$ ), but dry matter productivity (37,58 g vs $46,62 \mathrm{~g})$ and digestibility (47,46\% vs $57,01 \%)$ of field grass win over elephant grass..
\end{abstract}

Keywords: grass, production, dry matter digestibility

\section{PENDAHULUAN}

Rumput merupakan jenis hijauan yang menjadi komponen penting untuk keberlangsungan produksi ternak, meskipun memiliki kandungan nutrisi yang rendah akan tetapi rumput adalah pakan utama untuk ternak ruminansia. Peternak sapi, domba, dan kambing pada umumnya memelihara ternaknya dengan mengandalkan sumber pakan hijauan yang berasal dari rumput lapang yang ada di area tegalan. Selain rumput lapang sebagian peternak juga melakukan budidaya rumput untuk menyediakan pakan hijauannya.

Salah satu rumput yang sering dibudidayakan adalah rumput gajah. Rumput lapang/alam dan rumput gajah senantiasa diberikan oleh sebagain peternak disesuaikan dengan ketersediaannya. Hijauan merupakan sumber pakan utama ternak ruminansia, terutama sumber energi, sehingga untuk meningkatkan produksi peternakan ruminansia diperlukan juga untuk meningkatkan hijauannnya baik dari segi kuantitas maupun kualitasnya.

Salah satu langkah awal yang dapat dilakukan adalah dengan mengevaluasi potensi hijauan yang tumbuh secara alamiah serta rumput yang sengaja dibudidayakan tersebut. Hijauan yang dapat dimanfaatkan sebagai pakan yang baik salah satunya memiliki produksi berat segar dan berat kering yang baik serta memiliki tingkat kecernaan yang cukup tinggi. 


\section{MATERI DAN METODE}

\section{Metode Penelitian}

Bahan yang digunakan terdiri atas rumput lapang dan rumput gajah. Tanaman yang digunakan (rumput lapang dan rumput gajah) diambil sampel secara acak dengan menggunakan kuadrat ukuran $25 \times 25$ $\mathrm{cm}$. Tanaman dipotong $10 \mathrm{~cm}$ dari permukaan tanah kemudian ditimbang untuk mengetahui berat segar tanaman. Setelah itu dikeringkan dalam oven pada suhu $60^{\circ} \mathrm{C}$ selama 48 jam (AOAC, 1995). Pengukuran kecernaan bahan kering menggunakan metode Tilley dan Terry (1963). Metode ini digunakan untuk sampel hasil inkubasi yang kemudian divakum menggunakan alat pompa vakum khusus.

Sampel divakum menggunakan corong buchner lalu ditutup dengan kertas saring yang dibentuk sesuai corong, sampel dimasukkan ke dalam kertas saring sampai airnya habis. Sampel hasil vakum disimpan ke dalam cawan porselen, kemudian dipanaskan dalam oven suhu $130^{\circ} \mathrm{C}$ selama 4 jam. Sampel yang telah dioven dimasukkan ke dalam desikator, dan ditimbang bobot akhirnya sehingga diperoleh kadar air. Sampel kemudian diabukan selama 6 jam pada suhu $600^{\circ} \mathrm{C}$, dimasukkan kembali ke dalam oven selama 1 jam agar suhu sedikit demi sedikit menurun, kemudian dimasukkan kembali ke dalam desikator selama 1 jam dan ditimbang.

\section{Desain Percobaan}

Desain percobaan yang digunakan adalah rancangan acak lengkap, yang terdiri atas dua perlakuan (P1: Rumput lapang, P2 : Rumput gajah) dan sepuluh ulangan. Data diolah menggunakan uji t yang digunakan untuk melihat perbedaan produktivitas dan kecernaannya.

\section{Peubah yang Diamati}

1. Berat segar, diperoleh dengan menimbang hasil rumput yang telah dipotong $10 \mathrm{~cm}$ dari atas permukaan tanah

\section{Berat kering}

$$
\begin{array}{ll}
\text { BAHS = A }- & \text { B } \quad \text { BKH }=\frac{\text { A - BAHS }}{\mathrm{A}} \times 100 \% \\
\text { Keterangan: } & \\
\text { BAHS } & \text { : Berat Air Hijauan Segar (gram) } \\
\text { A } & \text { : Berat Sampel Hijauan segar (gram) } \\
\text { B } & \text { : Berat Sampel Hijauan Kering Oven (gram) } \\
\text { BKH } & \text { : Berat Kering Hijauan (gram) } \\
\text { Produksi BKH } & \text { : \% BKH } \times \text { Produksi Hijauan Segar }
\end{array}
$$

3. Kecernaan bahan kering (KcBK)

$$
\begin{aligned}
& =\frac{\text { BK Sampel }(\mathrm{g})-\text { BK Residu }(\mathrm{g})}{\text { BK Sampel }(\mathrm{g})} \times 100 \% \\
& =\frac{\text { BK Sampel }(\mathrm{g})-\text { BK Residu }(\mathrm{g})}{\text { BK Sampel }(\mathrm{g})} \times 100 \%
\end{aligned}
$$

\section{HASIL DAN PEMBAHASAN}

\section{Berat Segar}

Produksi berat segar dapat digunakan untuk menilai produktivitas tanaman dan menjadi indikator penting untuk pemberian hijauan pakan ternak. Suryanah (2015) menyebutkan bahwa untuk menghasilkan produksi yang optimal, ternak harus mendapatkan hijauan pakan baik secara kuantitas maupun kualitas untuk dapat memenuhi kebutuhan ternak. Pada Tabel 1 dapat dilihat bahwa rataan produksi bahan segar pada rumput lapang dan rumput gajah masing-masing adalah 256,35 g dan 220,93 g. Berdasarkan hasil analisis diketahui bahwa terdapat perbedaan produksi bahan segar $\left(t_{\text {hitung }}>t_{\text {tabel }}\right)$ antara kedua rumput yang diuji. Rumput lapang memiliki rataan produksi bahan segar yang lebih tinggi dibandingkan rumput gajah.

Menurut Tanjaya et al. (2020) bahwa daya dukung pakan merupakan kemampuan penyediaan hijauan pakan dari suatu wilayah tertentu. Salah satu hijauan pakan yang dihitung adalah rumput yang tumbuh alami. Selanjutnya menurut Jaelani et al. (2019) bahwa tingkat ketersediaan yang tinggi dibutuhkan ternak sehingga memudahkan dalam memperoleh pakan yang berguna sebagai sumber energi, protein, mineral, dan vitamin yang diperlukan oleh tubuh ternak. Ketersediaan hijauan harus terus menerus terjaga sehingga dapat memenuhi kebutuhan hidup pokok, produksi dan reproduksi.

Perbedaan produksi bahan segar dapat diakibatkan oleh umur pemotongan. Berat segar pada umur pemotongan yang berbeda dapat menyebabkan penambahan tinggi tanaman dan perbedaan jumlah anakan/ tunas. Menurut Suryanah (2015) bahwa semakin tua umur tanaman, maka terjadi penambahan ukuran tinggi pada batang yang disertai dengan peningkatan komponen dinding sel tanaman, penambahan anakan, dan jumlah daun sehingga produksi meningkat.

Selain itu produksi berat segar dapat dipengaruhi oleh faktor kesuburan tanah. Marassing et al. (2013) menyebutkan bahwa tanah merupakan unsur penting dalam pertumbuhan hijauan pakan karena tanah berfungsi sebagai tempat tumbuh, tempat memperoleh zat hara dan menjadi sumber air bagi tanaman sehingga apabila terjadi kekurangan unsur hara maka akan menganggu pertumbuhan tanaman yang ada di atasnya.

\section{Berat Kering}

Salah satu ukuran dari suatu pertumbuhan adalah produksi bahan kering, dimana 90\% kandungan bahan kering merupakan hasil dari proses fotosintesis (Goldsworthy dan Fisher, 1992). Produksi berat kering dapat dijadikan sebagai tolok ukur seberapa 
besar hijauan pakan yang akan diberikan pada ternak. Semakin tinggi berat kering, semakin sedikit pemberian pakan. Pada Tabel 1 dapat dilihat bahwa rataan produksi bahan kering pada rumput lapang dan rumput gajah masing-masing adalah $37,58 \mathrm{~g}$ dan $46,62 \mathrm{~g}$.

Berdasarkan hasil analisis diketahui bahwa tidak terdapat perbedaan produksi bahan kering $\left(\mathrm{t}_{\text {hitung }}<\mathrm{t}-\right.$ tabel) antara kedua rumput yang diuji. Rumput lapang dan rumput gajah menghasilkan produksi berat kering yang sama. Seperti halnya berat segar, produksi berat kering tanaman juga dipengaruhi oleh umur pemotongan. Semakin tua umur potong tanaman maka produksi bahan kering yang dihasilkan juga semakin meningkat.

Menurut Crowder dan Chheda (1982), peningkatan kedewasaan tanaman akan disertai dengan peningkatan bahan kering yang digambarkan dengan peningkatan komponen dinding sel dan penurunan komponen isi sel. Umur panen terbaik tanaman pakan adalah pada saat tingkat kedewasaan tanaman berada pada fase akhir vegetatif atau sebelum berbunga, karena pada periode tersebut produksi bahan kering hijauan yang dibentuk sudah banyak dan kualitas hijauannya masih cukup bagus.

Tabel 1. Rataan Produksi dan Kecernaan Bahan Kering Rumput

\begin{tabular}{lcc}
\hline \multirow{2}{*}{ Peubah } & \multicolumn{2}{c}{ Perlakuan } \\
\cline { 2 - 3 } & $\mathrm{P} 1$ & $\mathrm{P} 2$ \\
\hline Berat segar (g/petak) & $256,35 \pm 32,92$ & $220,93 \pm 7,99$ \\
Berat kering (g/petak) & $37,58 \pm 9,16$ & $46,62 \pm 13,17$ \\
KcBK (\%) & $47,46 \pm 1,52$ & $57,01 \pm 1,15$ \\
\hline
\end{tabular}

Keterangan :

P1 : Rumput Lapang

P2 : Rumput Gajah

\section{Kecernaan Bahan Kering}

Kecernaan bahan kering menunjukkan seberapa besar zat makanan yang ada di dalam pakan yang dapat diserap oleh tubuh ternak. Semakin tinggi koefisien cerna bahan kering (KCBK), semakin tinggi pula peluang nutrien yang dimanfaatkan ternak untuk pertumbuhannya (Tillman et al., 1998). Pakan yang berkualitas adalah pakan yang dapat memberikan manfaat yang tinggi. Rataan kecernaan bahan kering (KcBK) rumput lapang dan rumput gajah masing-masing 47,46\% dan 57,01\% (Tabel 1) . Rataan kecernaan rumput lapang penelitian ini lebih tinggi dibandingkan penelitian yang dilakukan oleh Nitis et al. (1985) dengan nilai 43,44\%, sedangkan rumput gajah penelitian ini setara dengan penelitian $\mathrm{Abdu}-$ rachman et al. (2005) dengan nilai 57,75\%.

Berdasarkan analisis, hasil menunjukkan bahwa rumput lapang dan rumput gajah memiliki perbedaan yang nyata $\left(t_{\text {hitung }}>t_{\text {tabel }}\right)$. Perbedaan tersebut dapat diakibatkan oleh adanya perbedaan kandungan protein kasar (PK) dalam bahan dan aktivitas mikroba rumen. Rumput gajah memiliki kandungan PK lebih tinggi dibandingkan rumput lapang, masing-masing 8,86\% (Adrianton, 2010) dan PK 6,70\% (Fathul et al., 2003). Oktariana et al. (2004) menyebutkan bahwa peningkatan kadar protein dalam pakan akan meningkatkan laju perkembangbiakan dan populasi mikroba rumen sehingga kemampuan mencerna pakan menjadi lebih besar. Dijelaskan pula oleh Van Soest (1994) bahwa kecernaan ransum pada ruminansia dipengaruhi oleh aktivitas mikroba rumen.

\section{SIMPULAN}

Simpulan dari hasil pemaparan di atas adalah:

1. Produksi berat segar dan kecernaan bahan kering pada rumput lapang dan rumput gajah memiliki perbedaan yang nyata, sedangkan pada produksi berat kering keduanya tidak terdapat perbedaan.

2. Produksi berat segar dan berat kering salah satunya dipengaruhi oleh umur panen tanaman.

3. Kecernaan bahan kering rumput dapat dipengaruhi oleh kandungan protein kasar dalam bahan dan aktivitas mikroba dalam rumen.

\section{DAFTAR PUSTAKA}

Abdurachman, S. Askar, dan I. Heliati. 2005. Penetapan Kecernaan Bahan Kering Rumput Gajah Secara in Vitro sebagai Sampel Kontrol. Prosiding Temu Teknis Nasional Tenaga Fungsional Pertanian 2005: $104-107$.

Adrianton. 2010. Pertumbuhan dan Nilai Gizi Tanaman Rumput Gajah Pada Berbagai Interval Pemotongan. Jurnal Agroland, 17 (3) : 192 - 197.

AOAC. 1995. Official Methods of Analysis. Association of Official Analytical Chemists. Benjamin Franklin Station, Washington.

Crowder, L. V. Dan H. R. Chheda. 1982. Tropical Grassland Husbandry. Ner York : Longman Inc.

Fathul, F., N. Purwaningsih, dan S. Tantalo. 2003. Bahan Pakan dan Formulasi Ransum. Buku Ajar. Universitas Lampung. Bandar Lampung.

Goldsworthy, P. R. dan N. M. Fisher, 1992. Fisiologi Tanaman Budidaya Tropik. Penerjemah : Tojaro. Universitas Gadjah Mada Press. Yogyakarta.

Jaelani, A., M.S. Djaya, G.K. Ni'mah dan A. Malik. 2019. Evaluasi komposisi botanis dan kandungan nutrisi pada rumput rawa kalakai (Stenochlaena palustris) dan purun tikus (Heleocharis dulcis Burm.) di Kecamatan Cerbon Kabupaten Barito Kuala. Pastura 9 (1):7-10.

Marassing, J. S., W. B. Kaunang, F. Dompas, dan N. 
Bawole. 2013. Produksi dan Kualitas Rumput Gajah Dwarf (Pennisetum purpureum) cv. Mott Yang Diberi Pupuk Organik Hasil Fermentasi EM4. Jurnal Zootek, 32 (5) : 158-171.

Oktariana, K., E. Rianto, R. Adiwinarti, dan A. Purnomoadi. 2004. Pemanfaatan Protein Pada Domba Ekor Tipis Jantan yang Mendapat Pakan Penguat Dedak Padi dengan Aras yang Berbeda. Jurnal Pengembangan Peternakan Tropis: 110115 .

Suryanah, S. 2015. Pengaruh Umur Pemotongan terhadap Produktivitas Rami (Boehmeria nivea (L.) Gaud) sebagai Hijauan Pakan. Thesis. Fakultas Peternakan. Universitas Padjadjaran. Sumedang.
Tanjaya, R., D. Hastuti, H. Wibowo dan A. Widiyani. 2020. Analisis daya dukung hijauan pakan ternak di Kecamatan Pulokulon Kabupaten Grobogan untuk Pengembangan Usaha Ternak Sapi Potong. Pastura. 10 (1): 53-57

Tillman, A. D., H. Hartadi, S. Reksohadiprodjo, S. Prawirokusumo dan S. Lebdosoekojo. 1998. Ilmu Makanan Ternak Dasar. Yogyakarta: Gadjah Mada University Press. Cetakan Ke-VI.

Tilley, J. M. A. and R. A. Terry. 1963. A Two Stage Technique for in The In-Vitro Digestion of Forage Crops. Journal Grassland Society.

Van Soest, P. J. 1994. Nutrition Ecology of the Ruminant. 2nd Edition. O and B Books, Inc. Corvalis. Cornell University Press. New York. 